\title{
Fotografia de poesia: devires da fabulação, durações em expansão e movimentos do instantâneo Laila Melchior ${ }^{1}$
}

\section{O cinema expandido e a problemática do dispositivo}

A noção de "cinema expandido" conceptualizada pela primeira vez por Gene Youngblood em 1970 buscava dar conta da emergência do vídeo e das novas tecnologias que, em diálogo com a forma estabelecida do cinema, abriam novos campos de possibilidades. Nesse momento muitas das práticas audiovisuais e tentativas teóricas de circunscrevê-las já apontavam tendências híbridas de um cinema que começava a tornar-se outro na medida em que assumia para si novas formas, novas questões. Mais recentemente, André Parente (2008) destacou como este "outro cinema maior que o cinema" - o "cinema expandido" - já era pressentido antes mesmo da conceitualização de Youngblood. Cunhado por artistas, o termo indicaria uma radicalização do cinema experimental por meio de "happenings" e "performances", projeções múltiplas, muitas vezes em espaços que não os da sala de cinema. Partindo da importância do advento do ví$\mathrm{deo}^{2}$ para um outro entendimento do que se poderia chamar cinema, Parente (2012) sublinha o papel do dispositivo cinematográfico ${ }^{3}$ que, ao se tornar evidente ${ }^{4}$, passava a implicar o desocultamento da produção de suas imagens, estas sempre processuais.

$\mathrm{Na}$ tradição dos estudos audiovisuais a noção de dispositivo remete, numa primeira acepção, à disposição das imagens uma vez dadas as dimensões arquitetónicas, tecnológicas e discursivas estabelecidas como cinema. O dispositivo entretanto, como caracterizado por Deleuze, é uma "meada", um "conjunto multilinear" (Deleuze,

\footnotetext{
${ }^{1}$ Universidade Federal do Rio de Janeiro, Escola de Comunicação (Eco-UFRJ), 22290-240 Rio de Janeiro, Brasil.

${ }^{2}$ E também de outros dispositivos vizinhos como, por exemplo, o audiovisual, a partir do qual Hélio Oiticica fez seus "quasi-cinemas" (2005). Oiticica (2005) chama atenção para o caráter fronteiriço do trabalho, em que "(...) o cinetismo do 'fazer rastro' e sua ‘duração' no tempo resultam em posições estáticas sucessivas como momentos-frame one by one que não resultam em algo mas já constituem momentos-algo em processo".

${ }^{3} \mathrm{O}$ dispositivo aparece nas obras de Michel Foucault (1988) e Gilles Deleuze (1996) dotado de positividade, apto a mobilizar disposições narrativas capazes de atribuir sentidos, agenciar forças, acontecimentos e propiciar linhas de subjetivação. Para mais sobre o dispositivo cinematográfico cf. Cinema em trânsito (Parente, 2011).

${ }^{4}$ Seja nas experiências contemporâneas do "cinema de museu" ou no primeiro cinema que, apresentado nas feiras e vaudevilles como forma de atração, ainda não tinha estabilizado os elementos que mais tarde viriam a ser confundidos com a própria noção de cinema.
} 
1996) que não é total, isto é, não instala configurações de uma vez por todas mas instaura processos, derivações. Em seu próprio funcionamento o dispositivo produz linhas de subjetivação que, por definição, estão a ponto de criar novos agenciamentos, novos dispositivos, novas linhas de subjetivação ${ }^{5}$. Os circuitos particulares que um dado dispositivo estabelece entre atualidades e virtualidades traçam processos específicos, escapam às determinações preexistentes por meio de novos arranjos cujas consequências são, em larga medida, indeterminadas. Neste sentido, é preciso notar como o advento do vídeo demarcou novos contornos para o cinema experimental e abriu-lhe um universo de imagens de identidades flutuantes. Paralelamente, as próprias balizas que separavam práticas artísticas supostamente díspares se atenuaram no cenário contemporâneo contribuindo para um enorme hibridismo de meios.

Cabe contudo notar que, para além desta primeira aceção arquitetónica, o dispositivo pode ser problematizado a partir de outros pontos de vista. Nomeadamente, a estratégia narrativa do dispositivo remete a um cinema do acontecimento ${ }^{6}$. Trata-se sobretudo de obras nas quais há uma produção de acontecimentos no contacto do filme (aparato, diretor, etc.) com o mundo para captar o contingente e enfatizar um aspeto em que o cinema confunde-se com o mundo. Agnès Varda, por exemplo, cria um dispositivo para Salut les cubains (1963) numa jornada a $\mathrm{Cuba}^{7}$. O filme assume tons ensaísticos, subjetivos, autobiográficos e epistolares que, segundo Consuelo Lins, cumprem a função de liberar a realizadora e o filme de "suas histórias pessoais, dos seus dramas, dos seus segredos, e capturar o que surge do seu encontro com o mundo" (Lins, 2007, 152).

Provocar acontecimentos nas imagens e no real passa a ser uma tática de disparo do novo neste momento de marcada expansão dos limites dos diferentes campos artísticos. Se o cinema vai em direção a seus próprios processos (antecampo, momento de feitura, ou mesmo a vida) ele também assume para si práticas de outros campos artísticos (como indica, por exemplo, a presença constante da fotografia em obras como La Jetée ou Salut les cubains). Neste sentido chama igualmente a atenção ao modo como, nos filmes produzidos a

\footnotetext{
${ }^{5}$ Um exemplo de quebra com configurações "normais" do dispositivo cinematográfico seria o caso de algumas obras em vídeo que se constituem a partir de circuitos fechados. Neles, a mudança no dispositivo (e basta que seja em um de seus elementos) consagrado no cinema se altera, se reconfigura e dá origem a novos agenciamentos e modos de subjetivação.

${ }^{6}$ Este cinema do acontecimento, se quisermos, aparece já nas reflexões de Deleuze (1990) sobre um cinema que se expõe às pressões do real, o cinema-verdade dos anos 1960, como veremos a seguir.

${ }^{7}$ Feito com fotografias de viagem da realizadora, o filme é inovador também no que diz respeito ao hibridismo de seus meios. Chama atenção esta tendência de influência omnidirecional borrando as fronteiras dos diferentes campos das artes. Um ano antes em La Jetée (1962) Chris Marker já havia realizado um filme quase inteiramente baseado em imagens fotográficas.
} 
partir da inflexão narrativa do filme-dispositivo, a ficção e o artifício aparecem cada vez mais como potências nos filmes de real, e não exatamente como discursos de verdade. Se por um lado o chamado "cinema-verdade" de cineastas como Jean Rouch e Pierre Perrault (do qual o filme-dispositivo contemporâneo pode ser visto como um desdobramento) ainda supunha uma distinção marcada entre fil$\mathrm{me} /$ mundo e narrador/narração, ele problematizava, por outro lado, a possibilidade mesma de narrar o real, e neste sentido a noção de dispositivo. Rompia-se assim com um ideal de verdade típico da ficção para dar lugar ao que Gilles Deleuze (1990) identificou como seu oposto: a função fabuladora ${ }^{8}$ dos pobres, intimamente ligada à invenção de um discurso indireto livre - mais especificamente de uma subjetividade indireta livre $e^{9}$ - que constituía essas narrativas do real.

O presente artigo dedica-se sobretudo à expansão desta maneira particular de pensar a imagem ao investigar o dispositivo como forma narrativa para criar imagens-fábula. Trata-se do processo de constituir imagens a partir de um meio de reprodutibilidade técnica em que o falso torna-se momentaneamente indiscernível do mundo, funda processos e sensibilidades de novos mundos a serem habitados - ainda que provisoriamente. O que Deleuze nota no cinema-verdade são dispositivos de criação de imagens no centro das dinâmicas de subjetivação e construção do real. Estas imagens da fabulação se opõem à ficção porque funcionam segundo um outro regime de verdade que, por sua vez não emerge exclusivamente no cinema mas se pode notar em inúmeras outras experiências artísticas. No que diz respeito à tradição visual, a pintura e própria fotografia já haviam se perguntado sobre as condições da representação para além dos regimes veristas de verdade influenciando outros campos de pesquisa e prática artística e contribuindo mesmo para criar condições que, nos anos 1960, permitiram a emergência do cinema-verdade. A prática dos tableaux vivants, por exemplo, difundida no século XIX como forma de divertimento em que atores imitavam plasticamente poses de quadros e estátuas conhecidos, já tangenciava tais aspetos. Também o faziam, de maneira ainda mais intensificada, as experiências de artistas como Claude Cahun ou Marcel Duchamp e Man Ray que, nas primeiras décadas do século XX, desafiavam o conceito de identidade e de género por meio da fotografia.

A questão da comuta entre real e ficcional nas narrativas documentais, portanto, embora não seja nova, parece ganhar um novo fôlego e assumir novas formas - nomeadamente pelo uso que faz do

\footnotetext{
${ }^{8}$ Segundo Deleuze $(1990,161)$ trata-se ainda de um aspecto que Nietzsche apontou sobre um ideal de verdade que só seria possível na ficção mais profunda do real, e que a própria veracidade da narrativa se fundava na ficção.

${ }^{9}$ Subjetividade indireta livre no sentido em que o cineasta abre mão das suas ficções para deixar sua personagem fabular. O filme, assim, passa a ser um ato de enunciação coletiva, obra de "duas cabeças, de mil cabeças", coloca Deleuze (1990, 183).
} 
recurso de uma subjetividade indireta livre - diante de algumas experiências da fotografia contemporânea. Este artigo irá dedicar-se em especial ao trabalho The adventures of Guille and Belinda and The enigmatic meaning of their dreams ${ }^{10}$ da fotógrafa argentinaestadunidense Alessandra Sanguinetti que parece tornar agudas algumas das questões mais relevantes no contexto da invenção ademais já anunciada na prática de outros fotógrafos - de uma forma de discurso indireto livre fotográfico ${ }^{11}$. A discussão em torno desta forma, por sua vez, remete à questão iniciada por Pasolini (1976) e retomada por Deleuze (1990) sobre a possibilidade de um cinema de poesia - que Deleuze endereça à questão das imagens diretas do tempo - que explorasse no cinema mais do que o recurso narrativo da prosa. A fotografia de poesia à qual este artigo se dedica é, portanto, aquela que se volta para o tempo para dele fazer imagens diretas preocupando-se antes com um aspeto da duração do que com a questão do instante, mais comummente discutida no âmbito da teoria da fotografia $^{12}$.

\footnotetext{
${ }^{10}$ Em português "As aventuras de Guille e Belinda e O enigmático significado de seus sonhos".

${ }^{11}$ Na página da artista o leitor encontrará uma versão quase completa do ensaio: (http://alessandrasanguinetti.com/).

${ }^{12}$ Não buscaremos insistir numa oposição ontológica da pose e do movimento. Em contrapartida retomaremos a noção de movimento que baliza os comentários de Deleuze (1985 e 1990) sobre o cinema privilegiando a imagem intermediária que (segundo a terceira tese de Bergson) é mudança e afeta o todo: é, portanto, da ordem da duração. Deleuze destaca como a questão do tempo, central na problemática da duração, não se confunde com progressão ou com a sucessão de instantes. Veremos a seguir como as fotografias de Sanguinetti, ao convocarem uma constelação anacrónica tem por efeito dar a ver uma imagem direta do tempo relacionando-se com as ideias de movimento/tempo que perpassam a obra de Deleuze. Se Roland Barthes (1984) anuncia o noema da fotografia como passado isto foi - ressaltamos algumas passagens em que o autor também indica uma imagem do futuro - a morte daquele que posa: "leio ao mesmo tempo: isso será e isso foi" $(1984,142)$. A ideia de duração que o presente artigo busca explorar corresponde, se quisermos, a este intervalo não mensurável que está em jogo na imagem. É neste sentido que o conjunto das fotografias de Sanguinetti designa uma mudança, um devir, que se confunde com a forma do discurso indireto livre como subjetividade indireta livre: enunciação coletiva que deixa ver estados de mudança no presente. Analogamente ao modo como embora o cinema opere "por meio de fotogramas, isto é, de cortes imóveis, vinte e quatro imagens/segundo" (Deleuze, $1985,9)$ e nos ofereça "como foi muitas vezes constatado" não "o fotograma, mas uma imagem media a qual o movimento não se acrescenta, não se adiciona", também este aspeto da fotografia diz respeito a um fluxo: para além do "corte imóvel", das "poses eternas" ou do "instante privilegiado", uma mudança que afeta o todo. Finalmente, poderíamos evocar a alusão que Deleuze faz a Epstein na definição de plano como "corte móvel, quer dizer, uma perspectiva temporal ou uma modulação" (1985, 34). A diferença entre a imagem cinematográfica e a imagem fotográfica decorria disto pois, segundo Deleuze: "a fotografia é uma espécie de 'moldagem': o molde organiza as forças internas da coisa de tal modo que elas atingem um estado de equilíbrio num certo instante (corte imóvel)" (1985, 34). Na medida em que se admite o aspecto duracional de um conjunto de imagens fotográficas esta separação cai por terra, permitindo a presente abordagem mesmo de uma perspectiva deleuziana.
} 


\section{Exposição do tempo}

As fotografias de Sanguinetti poderiam ser experimentadas no âmbito das expansões de um cinema e de uma fotografia que se "contaminam" mutuamente complexificando ainda mais as imbricações que aproximam os diferentes campos das artes no contexto contemporâneo. Ao fotografar as jovens primas Belinda Stutz e Guillermina Aranciaga ao longo de aproximadamente 10 anos protagonizando cenas quotidianas e brincadeiras no ambiente rural nos arredores da cidade de Buenos Aires, Sanguinetti utiliza intuitivamente recursos próximos àqueles destacados por Deleuze nas narrativas de real de orientação fabulatória. A artista cria imagens fotográficas carregadas de durações e ficções e instiga a discussão sobre um entendimento amplo do dispositivo na prática fotográfica ${ }^{13}$. O gesto de Sanguinetti, de voltar repetidamente ao convívio com as meninas e estimulá-las a fabular diante de seu próprio real, privilegia o rompimento com um regime de verdade baseado no referente ${ }^{14}$, um dos principais conceitos mobilizados por Roland Barthes (1984). Sua prática imbrica assim, a uma só vez, a superação de uma ideia de constância do sujeito e de uma forma homogénea, constante, do pas-

\footnotetext{
${ }^{13}$ Não que outros fotógrafos já não tivessem apontado problemáticas vizinhas a estas em seus trabalhos com o instantâneo. A começar por Muybridge e Marey, exemplos clássicos de fotógrafos preocupados com a duração implicada em imagens instantâneas e que, no entanto, serão criticados pelo Bergson de A evolução criadora por proceder no sentido de uma divisão homogénea do tempo que impediria a duração. No contexto contemporâneo, fotógrafas como Sanguinetti, Cindy Sherman e Sophie Calle - para além dos exemplos já citados de Claude Cahun e da dupla Duchamp/Man Ray - trabalham com um outro entendimento da duração, que prioriza a questão do falso potencializado pela imagem fotográfica, remetendo assim à questão do dispositivo e, eventualmente, à possibilidade da imagem-tempo fotográfica - ou uma fotografia de poesia - como este artigo pretende mostrar.

${ }^{14}$ Tendo já uma longa história nos estudos linguísticos, o termo referente - que na gramática indica um elemento designativo e em semiótica corresponde a um dos três componentes do signo (significante, símbolo e referente) - é convocado por Barthes para indicar uma natureza tautológica da fotografia, na qual algo do mundo real se dá a ver na imagem e a ela se cola de maneira definitiva. A despeito da grande importância deste estudo e do termo no âmbito da teoria fotográfica, esta noção de referente é problematizada neste artigo na medida em que privilegia o carácter indicial da fotografia (entendida como rastro de um objeto ou de uma pessoa encerrada em sua própria identidade, ou seja, numa fotografia em que "isso é isso, é tal" $(1984,14)$, como coloca Barthes) em detrimento do componente de duração (relação, afetividade, movimento) que buscamos aqui destacar como operações típicas de um discurso/subjetividade indireto(a) livre. Veremos a seguir como o horizonte de inflexões que abre espaço à fabulação na fotografia do discurso indireto livre parece uma perspetiva tão mais distante da experiência da fotografia quanto mais se lhe aproxima de um puro registro do instante. Nesse sentido, a opção presente de uma aproximação da fotografia com o cinema (e, consequentemente, a noção de cinema expandido aqui utilizada).
} 
sar do tempo: desafia a noção de instante ao convocar durações no conjunto de suas imagens estáticas ${ }^{15}$.

Em seu conjunto desordenado em relação à tomada cronológicas das imagens, as fotografias convocam o espectador a realizar um trabalho de montagem. Seja nos espaços de museus e galerias, seja na edição de seus fotolivros ${ }^{16}$, as fotografias de Sanguinetti remetem a imagens potentes do tempo não só na medida em que falsificam identidades por meio da fabulação (recurso de bifurcação do tempo, segundo Deleuze) mas pela própria forma de seu conjunto anacrónico. É no interior deste conjunto anacrónico que a artista propõe alguma separação, a saber dois momentos que compreendem grosso modo a infância e o princípio da vida adulta das personagens ${ }^{17}$. Assim, a partir do arranjo das imagens - e a despeito de sua inclinação

${ }^{15} \mathrm{O}$ instante como abstração, fração mínima do tempo, teria segundo Maurício Lissovsky (2006) inibido a esfera do invisível na fotografia (típica das práticas do séc. XIX) ao tornar supostamente apenas o real - o referente - visível. Nesse sentido a fotografia moderna, ao inventar o instante teria também banido seu componente de duração. Se por um lado "a releitura deleuziana das teses de Bergson sobre o movimento e o tempo foi capaz de salvar a temporalidade do plano cinematográfico de sua aparente subsunção ao movimento", insiste o autor, por outro lado "a fotografia como tal permaneceu refém da noção de uma instantaneidade artificial, que se abate sobre o tempo e a duração como a guilhotina do carrasco (...)" (Lissovsky, 2008, 60). Deleuze nega a afirmação de Bergson (2005, 60) de que o cinema não contaria com duração por tratar-se nele de um espaço homogéneo da inteligência e não do espírito. Em seus livros sobre o cinema Deleuze irá conferir à imagem em movimento aquilo que sob seu ponto de vista lhe era de direito e que Bergson não pudera admitir: sua duração. Nesta mesma direção que o presente artigo se permite destacar o aspeto duracional de um tipo de fotografia para ensaiar uma espécie de teoria do movimento própria ao fotográfico. Esta não se baseia na mecânica que do ponto de vista técnico origina a imagem fotográfica, mas numa compreensão ampla de duração e de movimento que, segundo Deleuze, é fluxo, variação de qualidade. O movimento aqui remete portanto "a uma mudança, migração, a uma variação sazonal" $(1985,16)$, que parece ser o objeto mesmo de algumas experiências fotográficas, entre elas a de Alessandra Sanguinetti.

${ }^{16}$ Como certa vez colocou Dominique Païni (2013), a edição de fotografias parece seguir a vocação de se fazer pelas mãos do próprio espectador, que folheia e ordena as imagens. Neste sentido Sanguinetti daria a seu espectador também a alternativa de montagem com seus pés: por meio de um percurso bastante livre no espaço da exposição, este edita a ordem dos acontecimentos reais como quiser, interpelando a vocação documental das imagens por outras vias, notadamente aquelas da criatividade.

${ }^{17}$ A escolha pela demarcação dos aspetos lúdicos e quotidianos da vida de Guille e Belinda conforme o período inicial do projeto (coberto pelo primeiro livro) e por um período mais tardio (coberto pelo segundo) parece corresponder mais a um aspeto ressaltado por Deleuze nos procedimentos do devir ficcionalizante das personagens do que a uma delimitação categórica das identidades constantes segundo um critério temporal. Como Deleuze coloca "é preciso que a personagem seja primeiro real, para afirmar a ficção como potência e não como modelo: é preciso que ela comece a fabular para se afirmar ainda mais como real, e não como fictícia. A personagem está sempre se tornando outra, e não é mais separável desse devir (...)" (Deleuze, 1990, 185). A separação dos dois momentos parece corresponder, de alguma maneira, a essa preocupação de mostrar o real para confrontálo à fabulação. 
documental - noções como antes e depois não parecem constituir questão a menos que sejam problematizadas por seu embaralhamento.

O carácter "constelacional" das imagens se acentua por meio de uma edição que acontece segundo o ritmo e as escolhas feitas no percurso do próprio espectador, na medida em que este se desloca em meio às fotos expostas na galeria ou folheia os volumes do fotolivro do ensaio. O contacto com a obra põe em marcha uma ambiguidade própria do visual que resiste à tentativa de racionalização e delimitação do real, típica do género documental. Esta ambiguidade ressoa nos próprios corpos das meninas, se faz visível como imagens deste período de potencialidade amorfa que é o da adolescência $^{18}$. É deste modo que o aspeto documental que à primeira vista poderia garantir um terreno estabelecido, um a priori que localizasse as imagens, quebra-se tanto com o vai e vem temporal das sequências quanto com a performance fabulatória mobilizada pelas personagens. Apropriando-se de certos meios já trabalhados em outros campos da arte, Sanguinetti produz imagens documentais de temporalidade imprecisa, que não oferecem exatidão sobre suas coordenadas. Se por um lado a presença constante do elemento natural participa como cúmplice das meninas e da realizadora (entre as funções de sujeito e de objeto das imagens, quase indiferenciada das próprias personagens); por outro lado, as diversas referências à cultura visual contribuem ainda mais para esta desestabilização espaçotemporal.

O tempo é tornado visível nestas camadas de imagens de ancoragens díspares. Mobiliza-se o arquivo infinito de um museu imaginário ${ }^{19}$, a partir do qual misturam-se referências longínquas, como na imagem em que Guille e Belinda flutuam sobre as águas de um riacho portando elegantes vestidos estampados. Com flores nas mãos e de olhos fechados, as meninas parecem mortas numa clara referência à Ofélia, personagem de Shakespeare. As Ofélias de Sanguinetti articulam verdadeiro e falso, atual e virtual, de modo que a artificialidade - que não é por isso uma mentira - faz da imagem o espaço onde o falso opera uma potência. Na imagem, Guille e Belinda

\footnotetext{
${ }^{18}$ Ao debruçar-se sobre o esquema da imagem-movimento, Deleuze $(1985,12)$ defende, por exemplo, o estatuto do desenho animado como figuras em movimento que pertencem ao cinema por seu estado de fluxo. Neste caso, a continuidade do movimento se opõe à pose. De maneira análoga o conjunto de fotografias de Sanguinetti não propõe figuras acabadas, mas descrições em processo.

${ }^{19}$ A ideia de museu imaginário, tal como formulada por André Malraux (1965), destaca a superação das fronteiras espaço-temporais na arte a partir dos processos de difusão da reprodutibilidade técnica, e em especial, da fotografia. O museu aparece como um espaço imaginário que habita o inconsciente e remete ao privilégio do homem moderno em estabelecer diálogos e relações por conhecer uma série de obras que do contrário permaneceriam distantes no espaço e no tempo. Não mais um lugar físico, nem de relações físicas, mas algo que se concebe mentalmente: "o museu imaginário é necessariamente um lugar mental. Não o habitamos, ele nos habita" (Malraux, 1965, 123).
} 
são, a uma só vez, elas próprias e um outro ${ }^{20}$, a Ofélia. As meninas dão corpo à personagem na medida em que se apropriam de algo dela. Ao revolver o arquivo do museu imaginário, Sanguinetti e as meninas não performam uma, mas duas Ofélias: duplicam a personagem numa composição inusitada. Para além da própria personagem, a imagem poderia remeter ao feminino que nela se duplica ${ }^{21}$. Trata-se, portanto, de uma imagem dos sonhos das meninas que, no limite, incorpora algo de novo às suas próprias histórias. Mais do que simplesmente evocar a Ofélia como personagem abstrata e indeterminada, Guille e Belinda lhe dão corpo, performam suas próprias versões. Se elas o fazem de maneira plasticamente semelhante à célebre pintura de John Everett Millais, isto não acontece sem que se adicione novas camadas de historicidade à própria imagem.

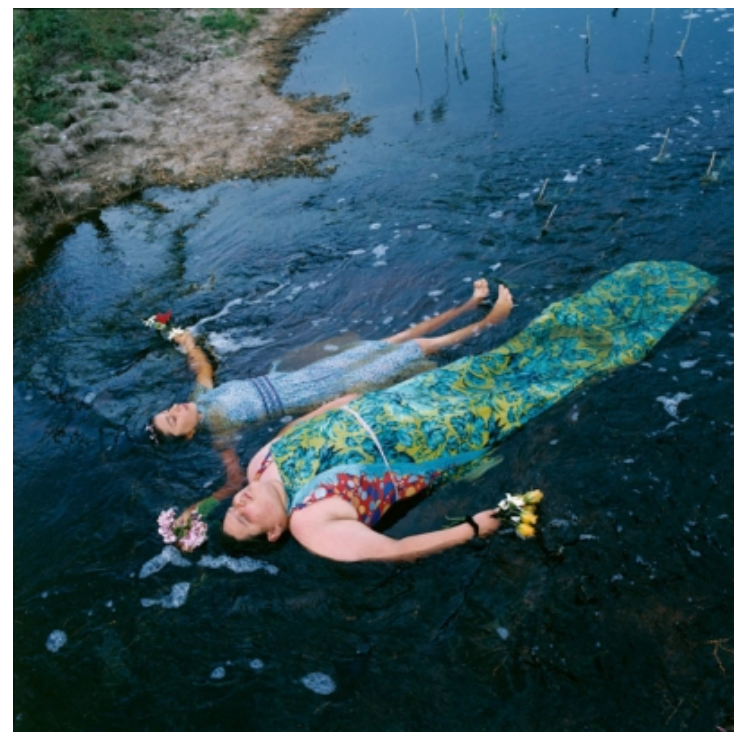

Imagem 1: Ophelias | (c) Alessandra Sanguinetti

\footnotetext{
${ }^{20}$ Tornamos à questão do discurso indireto livre e da subjetividade indireta livre tal como ela aparece na reflexão de Gilles Deleuze (1990). A propósito do ideal de veracidade na base dos discursos de real mobilizados pelos filmes documentários, o autor identifica um funcionamento típico da ficção em que a visão do diretor e aquela de suas personagens estão delimitadas por um discurso identitário do tipo $\mathrm{Eu}=\mathrm{Eu} ;$ Eles = Eles. Neste caso aspectos objetivos e subjetivos determinariam atribuições do autor e da personagem, delimitariam lugares de fala e de autoridade sobre o real que está sendo contado. Na inflexão indireta livre do real, o eu tornase outro, segundo Deleuze, e este é o terreno da fabulação.

${ }^{21}$ A pesquisadora norte-americana Elaine Showalter aponta a mitologia em torno da Ofélia como discurso sobre a loucura feminina. Seu afogamento duvidoso (sobre o qual paira a suspeita de suicídio) diria respeito a algo do próprio mistério feminino. A pesquisadora chama atenção para uma diferenciação entre a loucura de Hamlet e aquela de sua noiva Ofélia: enquanto a melancolia dele aparece associada ao intelecto, Ofélia sofreria de erotomania, doença cujos sintomas seriam de ordem emocional. Os efeitos desse discurso seriam notáveis também nas interpretações da personagem nos palcos de teatro. Se na época de Shakespeare as personagens femininas eram comumente interpretadas por homens no teatro, em torno de 1660, com uma maior difusão das atrizes, era comum a superposição entre a identidade das atrizes que interpretavam a personagem e o próprio papel. Segundo ela "as atrizes mais celebradas que interpretaram Ofélia foram aquelas associadas a rumores de decepções amorosas” (Showalter, 1985, 80).
} 
Instâncias objetivas e subjetivas embaralham-se no ensaio na medida em que as imagens dão a ver um todo quase indiscernível de corpos púberes e exuberância, originais e cópias, duração e instantaneidade. As meninas, no trabalho com a fotógrafa, montam as imagens que tomam emprestadas de um arquivo comum e imaginário. A relação íntima com a fotógrafa lhes garante certa confiança e o espaço ao redor envolve os corpos, participa de seus processos por meio de uma potência sensual e enérgica. A referência ao ambiente objetivo das personagens parece assim menos importante do que a abordagem da atmosfera que elas constroem para si durante as brincadeiras. A ideia de sonho que se pode destacar no título de The adventures of Guille and Belinda and The enigmatic meaning of their dreams remete em muitos aspetos à fotografia de inspiração surrealis$\mathrm{ta}^{22}$ - dentre outras referências como, por exemplo, a da montagem cinematográfica - onde os processos particulares que poderiam corresponder aos mecanismos de condensação e deslocamento reenviam a trocas constantes entre atual e virtual, objetivo e subjetivo, individual e coletivo. Tais perseguições recíprocas culminam numa inclusão do sonho e do imaginário não somente em oposição a um real imediato mas também às relações localizáveis do tempo linear ${ }^{23}$.

Trata-se de uma indeterminação que permite ao intervalo de base documental, referencial (e a princípio mensurável) que corresponde ao período da tomada das imagens reconfigurar-se a cada vez do ponto de vista visual. Não há portanto a pretensão de um desdobramento lógico do tempo. Tampouco a noção de progressão. O devir e sua natureza desprovida de estado final (que não projeta uma identidade mas é um estado de variação) parece ser o aspeto cinético por

\footnotetext{
${ }^{22} \mathrm{O}$ trabalho da alemã Grete Stern, por exemplo, criava imagens de orientação surrealista utilizando a montagem fotográfica como collage. As imagens da série Sueños (1948-51) que ilustrava a coluna El psicoanálisis te ayudará da revista feminina argentina Idílio eram feitas em estúdio e montadas a partir do relato de sonhos que leitoras enviavam para serem analisados, acompanhando os textos analíticos. O elemento onírico, assim como no trabalho de Sanguinetti, convoca uma forma de fabulação articulada ao real. Se em Sanguinetti é a performance que quebra o discurso do referente como real cronológico, em Stern é a collage que insiste nas lacunas de sentido desafiando o próprio discurso médico das análises superficiais oferecidas pela revista.

${ }^{23}$ O próprio carácter "constelacional” das imagens, sua possibilidade de construção por meio de montagens, condensações e deslocamentos poderia ainda lembrar a obra do pensador alemão Aby Warburg que se dedicou à construção de uma "história da arte" sem palavras e em novos termos (de inspiração sobretudo imagética), uma história da arte em movimento, como colocou o teórico francês Georges Didi-Huberman (2004). Em Warburg, é também o carácter anacrónico de uma constelação de imagens que aproxima intervalos no tempo e no espaço, memórias pessoais e coletivas.
} 
excelência nestas imagens ${ }^{24}$. É ao debruçar-se sobre suas próprias infâncias que Guille e Belinda tornam-se mulheres: criam imagens do feminino num quotidiano lúdico. Nenhum rito excecional marca esta passagem e, assim, nenhuma forma documental pode a ele referir-se. Trata-se antes da fotografia como processo e duração, fotografia como cinema, imagem-movimento no sentido de mudança de qualidade. Esta prática fotográfica instaura um jogo em que se questiona a própria constância da forma, a possibilidade de circunscrever identidades e, junto disto, o género documental, que aqui tende muito mais ao ensaio.

\section{Performance fabulatória}

No que concerne à feitura do ensaio, Sanguinetti (2003) conta ter-se esforçado para captar o final da infância das meninas entrando em seus espaços imaginários. A importância da participação da própria fotógrafa com seu aparato neste contexto, provocando situações e acontecimentos, já indica a vizinhança com uma abordagem do dispositivo tal como ele surge a partir do cinema de real dos anos 1960 que não mais supõe o registro do mundo in natura, mas busca uma experiência compartilhada ${ }^{25}$. Trata-se da invenção em grupo, de uma espécie de jogo que negocia a feitura das imagens e é fundado e mediado por elas. Se a fotógrafa permanece fora de quadro sua presença ainda assim se faz sentir dentro dele. No exemplo da imagem das Ofélias, o que transparece essa presença é uma teatralidade dirigida seja ela sugerida ou simplesmente proposta - que evidencia a experiência da imagem como enunciação coletiva.

\footnotetext{
${ }^{24}$ No contexto da análise das imagens de Guille e Belinda à luz de Deleuze tornase também interessante notar o caráter menor do devir. Segundo Deleuze (1996), não seria possível entrar num devir-homem pois o homem é a forma dominante. É nesse sentido que o trabalho de Sanguinetti, feito em colaboração com Guille e Belinda, explora um devir-mulher como principal elemento do fluxo de crescimento das meninas. O fluxo, no entanto, não é homogéneo. Quando, em suas performances as personagens e a própria fotógrafa furtam-se às formalizações, brincam em conjunto instalando-se entre a forma adulta e a infantil, exploram o intervalo de indiscernibilidade, diferentes graus entre essas duas zonas.

${ }^{25}$ Aqui a aproximação com os procedimentos do cinema e das outras artes em expansão parece estar relacionada principalmente ao carácter coletivo de uma experiência sempre mediada pelo outro. Em Rouch e Perrault - tanto quanto em Sanguinetti - trata-se de realizadores que se voltam para a vida, dirigem-se a realidades externas, compartilham modos de ficcionar com seus personagens. Não se trata da "ficção do real" nem da "ficção do referente" circunscritas nos ideais veristas de verdade. Tampouco falamos da ficção pura e simplesmente. É antes um encontro entre estas duas esferas que cria o que, a seguir, tentaremos conceptualizar sob o nome de "documental imaginário".
} 


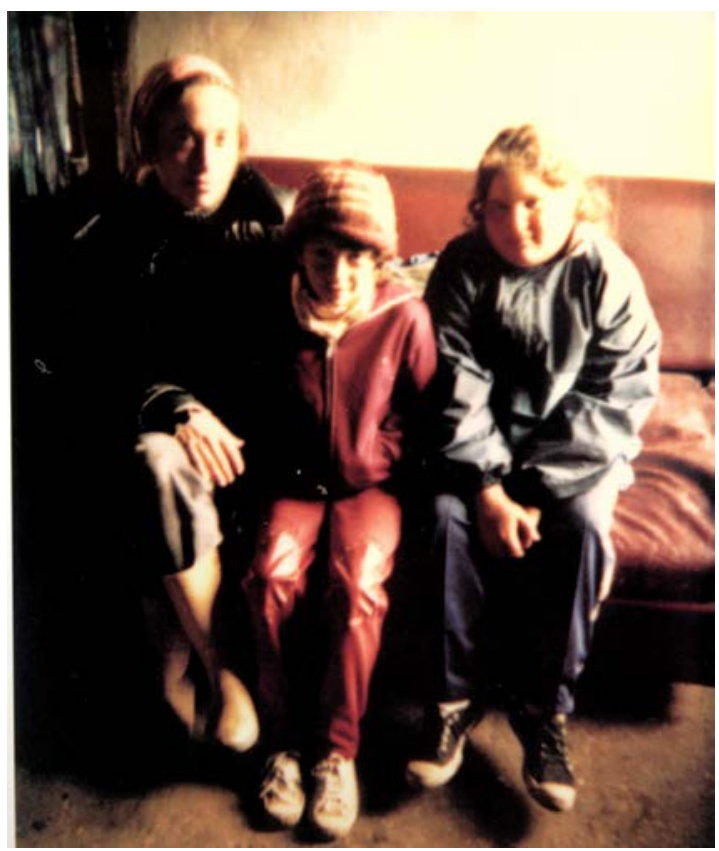

Imagem 2: Alessandra, Belinda e Guillermina | (c) Martin Weber

Numa única fotografia, no entanto - uma imagem exclusiva da edição do trabalho na forma de livro - Alessandra, Guillermina e Belinda aparecem no mesmo campo imediatamente visível. A fotografia parece espontânea, registra as três posando para a imagem, sentadas num sofá, apertando-se para caber no enquadramento. Todos os aspetos apontam para um registro informal, e a discrepância da imagem comparada ao restante do ensaio torna-se intrigante. A inserção desta imagem na sofisticada narrativa imagética proposta pelo livro da artista sugere o jogo subtil de atribuições e identidades fluidas: um jogo fundador que contamina as imagens e espalha-se pelo ensaio que segue. As três olham e sorriem para a câmara, deixando transparecer uma certa fragilidade, patente na postura corporal retraída do grupo que não encontra par ao longo do ensaio. Sanguinetti, ao lado de suas personagens, também está na posição de modelo. Na medida em que o olhar adulto e responsável do fotógrafo anónimo se dirige às três num ligeiro plongé, a fotógrafa parece relativizar sua própria autoridade. Desde de cima, uma câmara que não é a sua registra a visita, mostrando-a ao lado das meninas: as três sorriem, prevenidas do rito que nesse instante as toma como imagem. E assim, se Sanguinetti assina tudo o mais em seu próprio ensaio, esta fotografia parece cumprir a função de lembrar-nos que, ainda, algo escapa.

$\mathrm{Na}$ medida em que passeia pelas fotos, o espectador trabalha sua própria descodificação deste jogo de presenças, ausências e atribuições. Na condição de modelo, a imagem de Alessandra interroga sobre o estatuto dos papéis em vigência no trabalho. Se esta imagem - ainda que não tenha sido feita pela fotografa - ao dispor de sua figura não deixa de lhe dizer respeito; tampouco as imagens que faz das meninas lhes são estranhas. Uma das questões que se repete ao 
longo do contacto com o trabalho é: ainda que sejam formalmente de autoria da fotógrafa, de que maneira essas imagens remetem a Guille e Belinda, suas próprias aventuras, seus sonhos? E também, ainda que sejam fotografias de Guille e Belinda, em que medida os significados e enigmas mobilizados nestas fotografias são aqueles de Sanguinetti? Essas fotos dizem respeito a Guille e Belinda tanto quanto a Sanguinetti: uma partilha constará sempre das eventuais formulações sobre a quem se possa atribuí-las ${ }^{26}$. As meninas, para além de seu crescimento biológico abordado nas imagens, a despeito da cronologia linear que a todo momento ameaça a anacronia do conjunto, colandose às figuras na medida mesmo em que elas se tornam visivelmente adultas, estão engajadas num outro modo de construção de si, um modo falsificador. Também a fotógrafa, quando faz imagens da infância (remetendo à sua própria infância) mediadas pela experiência com as meninas abdica do mito do referente para aderir às durações de um encontro.

Assim, o ensaio remete à construção de imagens de um eu que escapa em direção ao outro no qual se torna. Deleuze já apontara este processo como construção de um tipo de imagem direta do tempo no cinema em que não apenas a personagem se torna outra no processo de fabular (sem nunca ser fictícia), mas também o cineasta - nesse caso, a fotógrafa - admite um outro para si quando a fabulação das personagens reais substitui sua própria ficção. A fotografia em que Alessandra Sanguinetti aparece ao lado das meninas parece menos relacionada à forma de um documento no estilo "making off" do que a marcar este detour afetivo, a relação que funda as imagens numa duração. Aqui a mise-en-scène honesta e encabulada parece conferir às poses seguras e plasticamente pensadas do resto do ensaio, por contraste, a ideia de um conjunto funcional e engajado. Marca-se a presença ativa - embora objetivamente invisível - de Alessandra como elemento das performances de Guille e Belinda.

A dedicação da fotógrafa, que retorna para mais uma vez empenhar-se ao tempo da fabulação na companhia das duas meninas, adquire contornos visíveis nos próprios gestos de Guille e Belinda, em seus corpos e nas formas que eles adquirem usando da artificialidade da performance como recurso de tornarem-se outro. Giorgio Agamben (2000) notou como o alargamento do campo cinematográfico implica debruçar-se sobre os elementos éticos, estéticos e políticos que, contidos no próprio cinema, apontariam à centralidade do gesto. Para o autor, a noção de gesto estaria ligada ao argumento

\footnotetext{
${ }^{26}$ Do mesmo modo que a própria língua permite dizer tratar-se igualmente de fotografias de Alessandra Sanguinetti, tanto quanto de fotografias de Guille e Belinda.
} 
deleuziano em torno da "imagem-movimento" ${ }^{27}$, estendendo-se para além do contexto estritamente cinematográfico e referindo-se ao estatuto da imagem de maneira mais ampla. As fotografias de Sanguinetti problematizam o passar do tempo e, em termos bastante bergsonianos, poder-se-ia dizer que nelas o corpo e o espírito se exprimem de forma peculiar, distinguindo-se por vezes e encontrandose por outras na medida em que o tempo passa nas suas duas formas: aquela que poderia ser registrada por um relógio e aquela imensurável, da duração.

Deleuze (1990) irá retomar a discussão da duração em Bergson no seu pensamento sobre a fabulação de personagens reais. A imagem-fábula que o autor destaca é imagem direta do tempo por deixar ver estados de mudança no presente. É a introdução do tempo como forma - em sua visibilidade - o que elevaria a fabulação ao campo da arte. O paradigma da forma do tempo que em Deleuze torna possível um elogio da fabulação é aquele cujo primado não é conferido nem ao passado nem ao presente, mas ao futuro, aquele de um povo por vir. Para o autor essa seria uma narrativa do "eu" que não se define pelo seu presente (o sujeito como hábito) nem pela fórmula do passado e da memória (seja ela voluntária ou involuntária) mas pelos aprendizados futuros que, ao estabelecerem relações com o passado, permitem experimentar o tempo. Trata-se do passado que não foi vivido, mas justamente que só pode ser narrado/ reinventado pelo trabalho da arte. A arte, por sua vez, como conjunto de relações produzidas, guarda distâncias, diferenças em relação à vida. Neste sentido nenhuma forma documental poderia corresponder a um ideal de verdade, de real. "Memória, eu te odeio", dizem Deleuze e Guattari (2007). Trata-se de marcar a experimentação do tempo para além da memória, além de qualquer referente do real. Não uma evocação nostálgica do passado, mas uma generalidade a ser experimentada para além do sujeito: em sua impessoalidade, inorganicidade. Deleuze argumenta que, contrariamente ao que Bergson defendeu, o cinema torna-se arte ao ficcionalizar o real. Sua potência: ficcionalizá-lo, não reproduzi-lo. A arte criaria mundos na medida em que os simula e não em que os reproduz.

A fórmula da narrativa simulante é justamente aquela em que o eu é outro. Ao voltar-se para o real - no cinema de Rouch e Perrault, exemplos de Deleuze (1990) - ela não estabelece uma relação de continuidade orgânica com ele. A imagem falsa do real, que não se submete a uma referência empírica fora da imagem e que não se propõe o modo de funcionamento da ficção só será possível fora da

\footnotetext{
${ }^{27}$ Agamben (2000) argumenta que, na esteira de Henri Bergson (2005), Gilles Deleuze (1990) teria abolido a clássica distinção da imagem como realidade psíquica e do movimento como realidade física por meio do conceito de "imagemmovimento". À diferença de Bergson, no entanto, Deleuze identifica cortes móveis nas imagens em movimento do cinema que estariam, portanto, em movimento por si mesmas e não somente graças à técnica cinematográfica.
} 
relação verídica com o real. Ficcionalizar a realidade, fabulá-la, seria a forma de "desformatar" o real ao modelo abstrato da ficção. A fabulação das personagens reais rompe a relação verídica com a vida quando se apresenta como sistema produtor de imagens além de todo o real. Neste devir outro do homem que abandona seu hábito para fabular passados possíveis e bifurcações do tempo não há mais a necessidade das distinções de ordem identitária entre objetividade e subjetividade: daí a forma da subjetividade indireta livre ${ }^{28}$, como zona de contaminação das identidades.

O espaço da ficção perde a primazia sobre as formas de vida e estas duas instâncias se confundem na narrativa simulatória em que personagens reais metem-se a fabular. A fabulação resgata a relação entre a vida e a ficção e, ao fazer daquela algo ficcionalizável inventa mundos para habitar. Com Deleuze, a arte torna-se potência na medida em que a imagem-fábula torna o tempo visível em seu devir: "seu paradoxo está em introduzir um intervalo que dura no próprio momento" (Deleuze, 1990, 188). Assim, "mais do que nos oferecer uma indiscernibilidade, ela nos faz ver o corpo enquanto um campo de forças, enquanto um campo de intercessão de forças" (Pimentel, 2010, 140). Na fabulação, o tempo que se torna visível faz do corpo uma conexão paradoxal entre orgânico e inorgânico. A performance dos corpos adolescentes nas imagens de Sanguinetti está ligada precisamente a esta potência fabuladora, que afirma o real e permite às personagens e à artista tornarem-se outros.

As vozes e falas das personagens são os elementos que Deleuze destaca no cinema, por meio da montagem, para marcar a separação entre os pontos de vista do cineasta e da personagem, sua gradual convergência (documentário tradicional) ou sua indiscernibilidade (subjetividade indireta livre). Ainda que estes elementos não possam encontrar nenhum correspondente direto na imagem fotográfica, cabe destacar como restam ainda alguns recursos de contaminação. No horizonte da imagem fotográfica a zona de indiscernibilidade entre a visão do fotógrafo, o ambiente fotografado e a visão de seus modelos fará da performance fabulatória um recurso

\footnotetext{
${ }^{28}$ Deleuze (1990) destaca como o cinema de real que o interessa promove uma quebra da veracidade narrativa que adequa sujeitos e objetos ao entender por "objetivo" o que a câmara vê e "subjetivo" o ponto de vista da personagem. Na forma do discurso indireto livre (possibilidade de um cinema de poesia) não há mais distinção clara entre a visão subjetiva da personagem (sua visão direta) e a visão objetiva da câmara (visão indireta da história). O discurso indireto livre inventado por Pasolini (1976) e retomado por Deleuze faz uso de uma câmara que adquire uma visão subjetiva e interior, que entra em relação de simulação da maneira de ver da personagem, como uma subjetividade indireta livre. Este tipo de narrativa não remeteria ao ideal de verdade da ficção e, portanto, não se pretenderia mais do que uma pseudo-narrativa. A imagem deixa de servir-se exclusivamente dos recursos da prosa (anda que convertidos à linguagem cinematográfica). Abole-se assim os dois tipos de imagem que corroboravam para a narrativa tida como verdadeira, baseada na lógica identitária do tipo "Eu = Eu".
} 
privilegiado $^{29}$. É este o papel do jogo no trabalho de Sanguinetti com Guille e Belinda: convocar a performance como recurso da permeabilidade das visões e das identidades.

A potência da artificialidade, do falso e do construído toma corpo no espaço forjado pela performance das meninas. As imagens que Sanguinetti apresenta da adolescência não são de puros processos orgânicos e biológicos, mas são permeadas a todo momento pelo inorgânico da fabulação. A própria natureza fotografada não se separa dos processos da cultura e não pode ser documentada em sua pureza, mas somente como engrenagem do artifício e da performance. A encenação de situações e personagens inventados, ou pertencentes a contextos alheios àquele imediato das meninas é, no contexto da fotografia, a fabulação que dá corpo à imagem, e não deixa de pôr em jogo uma herança teatral. Esta tendência à encenação será explorada de maneiras complexas, como condição ambígua dessas imagens que, ao mesmo tempo em que se oferecem como registros de uma vida que passa, são também recursos para sua passagem. A fotografia é o próprio rito mediador da imaginação tal como outrora, no cinema, o dispositivo fílmico impulsionava a partilha como elemento do próprio filme. Não se trata mais de documentar um ambiente, um modo de vida, mas de abrir caminho nas imagens em direção a uma série de outras imagens. Assim, os objetos locais perdem a sua importância. Já não são eles a conferir os significados implícitos ou descodificáveis nas imagens, mas são os corpos que cumprem esta função ao performarem o próprio acontecimento. Liberado pela performance que não se pretende real, mas que é fabuladora, o elemento onírico materializa-se e simboliza nos corpos, não nos objetos que os cercam. Trata-se agora de sonhos postos em ato, num jogo fabulatório de uma performance que se desenrola a partir do encontro-dispositivo mediado pela fotografia. Se por um lado há urgência em retratar algo que passa e se extingue a cada dia, por outro lado o ensaio instaura um fluxo cuja potência independe de qualquer urgência, dá-se no sem-tempo da fábula, no infinito das tardes no pampa, na duração desinteressada: desprovida de qualquer propósito que não aquele de criar imagens.

Assim, apesar de documentais, essas fotografias serão sempre, também, imaginárias - imaginadas. Serão imagens povoadas de sonhos, desejos e medos aos quais se dá corpo nos gestos de Guille e Belinda, nos corpos que se voltam para o real sem estabelecer conti-

\footnotetext{
${ }^{29}$ Alternativamente, nas imagens de orientação surrealista de Grete Stern (cf. nota 18) é a collage que cumpre esta mesma função. Suas fotografias usam a indeterminação e a variação de planos subjetivos e objetivos como recurso (remetendo respetivamente à visão da personagem e à visão do todo do sonho) criando imagens em que as identidades já não se delimitavam com nenhuma precisão. Na série "Sueños" as vistas se confundem e se contaminam na medida em que os conteúdos fantásticos, assim como mitos, promovem identificações, ligando sujeitos, produzindo novas formas de subjetivação, também como subjetividade indireta livre.
} 
nuidade orgânica com ele. Neste sentido é interessante notar como nas fotos em que Guillermina e Belinda aparecem mais velhas e em suas vidas quotidianas, lá, ainda assim, violenta-se o passado para que o tempo se torne visível. O passado adquire uma densidade na qual é dado ao espectador instalar-se, assim como fazem as meninas em suas brincadeiras. Suas poses e referências são mais do que imitações, são invenções de passados e de futuros (com)possíveis. O fato de que as imagens sejam propostas por Sanguinetti, realizadas e retomadas pelas meninas indica a ausência de limites precisos entre subjetividade e objetividade: o território do falso, ainda que fundado inicialmente sobre o real, põe as identidades em risco. Ao performarem seus diversos papéis, Guille e Belinda instalam-se no tempo, nas dobras inorgânicas, num certo desinteresse em relação ao mundo "real" que a condição da brincadeira proporciona. Ao invés de realizarem simples imitações, seus corpos se põem em movimento, falsificam o passado, se desdobram em múltiplas potências fabulatórias.

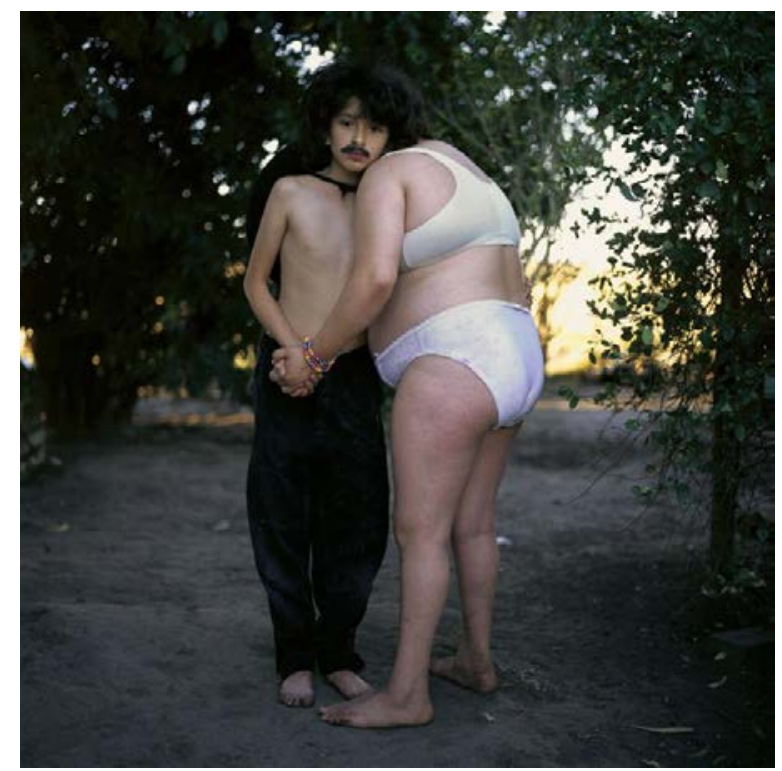

Imagem 3: The couple | (C Alessandra Sanguinetti

\section{Documental imaginário}

Pensadas inicialmente em relação sobretudo ao cinema, essas considerações indicam expansões de determinados procedimentos que ultrapassam o próprio campo cinematográfico e constituem problemas próprios à arte. Um exemplo disto seria o conceito de 
documental imaginário ${ }^{30}$ que, surgido no cinema, tem-se legitimado no campo da fotografia na medida em que aparece no vocabulário mobilizado por artistas e pensadores para designar uma parcela da produção contemporânea que tensiona os limites das expectativas de um ideal de veracidade associado às imagens da reprodutibilidade técnica. Em relação à imagem fotográfica, o documental imaginário questiona um discurso positivista do real, historicamente ligado à representação fotográfica como documento. O decair do pensamento positivista encontra na positividade dos dispositivos um horizonte de possibilidade para novos regimes de verdade. Neles não se supõe o ideal verista do real mas a mediação, o encontro, as formas de subjetivação que acontecem por meio do recurso de fabular, de estabelecer nas imagens pontos intermediários entre objetividade e subjetividade.

Nas fotografias de Alessandra Sanguinetti se estabelece um jogo que deixa ver sua relação com Guille e Belinda, termos construídos e negociados em conjunto, como invenções de fábulas. Neste sentido trata-se sempre de um "documental oblíquo", uma forma de "discurso indireto livre". Além dos recortes sociais de uma dada realidade, as operações de Sanguinetti destacam, por meio da corporeidade das personagens, uma série de afetos e aspetos psicológicos que se inscrevem no contexto de uma duração estendida. O carácter documental do conjunto de fotografias relaciona-se ao fato de que modelo, fotógrafa e espectador, cada um a seu modo, estão empenhados na fabricação destes documentos-fábula: a partir da longa abordagem que Sanguinetti dá a ver e da montagem por condensações, deslocamentos, e interpretações livres, todos participam da construção de sentidos e significados. Fragmentos e sensações que supõem uma feitura numa duração, montam séries, implicam leituras, etc., tornam-se parte deste carácter documental de atmosfera flutuante, fundado sobre temas tão vastos e abrangentes quanto identidade, lugar, não-lugar, corpo, pertencimento, etc. A fo-

\footnotetext{
${ }^{30}$ Documental imaginário é a expressão de Bazin (1959) para designar a regra do cinema segundo a qual a montagem jamais pode simular o que é, por direito, da ordem da ontologia fílmica e fotográfica. No contexto da fotografia, a expressão adquire uma aceção todavia distinta: surge na fala do artista e curador canadense Chuck Samuels (2004), que a evoca durante o prémio brasileiro Foto Arte 2004 para definir o trabalho Paisagens Submersas, dos fotógrafos João Castilho, Pedro David e Pedro Motta. Deste modo, o termo fazia referência ao aspeto subjetivo dos ensaios do coletivo no trabalho de documentação do processo de inundação das terras na região do Vale do Jequitinhonha, Minas Gerais, em função da construção de uma usina hidroelétrica. As fotografias de Castilho, David e Motta, apesar de profundamente ligadas aos acontecimentos do Jequitinhonha - ou talvez por isso dão vazão a uma abordagem um tanto abstrata de modo que o trabalho trata sobretudo das dimensões emocionais do acontecimento. Realizado ao longo de anos de pesquisa, documentação e aproximação com os moradores locais, as imagens constituem um inventário de suas memórias e expectativas, a despedida da terra natal, uma paisagem às vésperas de tornar-se submersa, junto com fragmentos de lembranças vividas e esperanças associadas à nova vida, fora dali.
} 
tografia acede assim às questões do tempo que faz visível por meio de múltiplos elementos que transbordam as próprias imagens ${ }^{31}$.

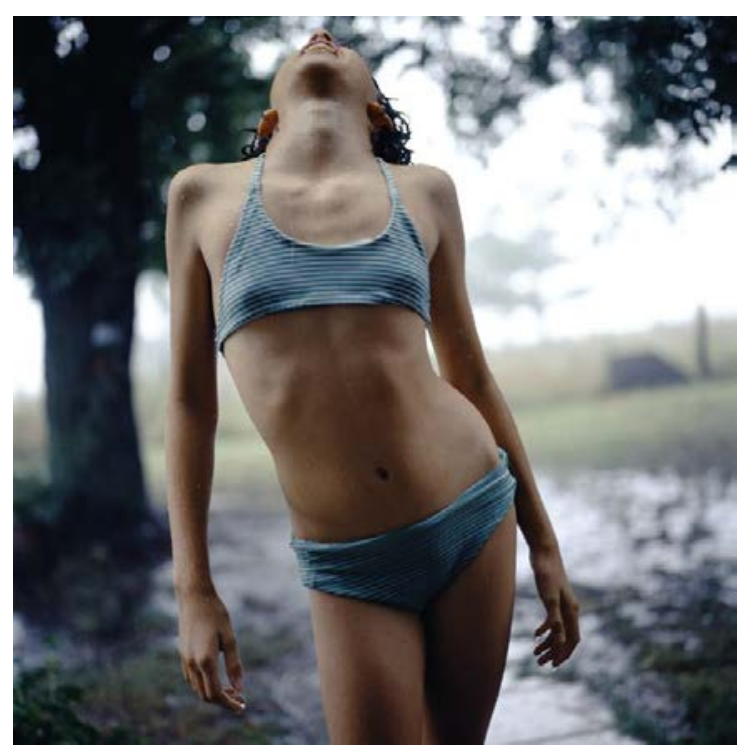

Imagem 4: Rain | (c) Alessandra Sanguinetti

Se não há mais a suposição de um real puro que possa ser fotografado de tal ou qual maneira, nem a noção de acontecimento mediático, existe contudo a busca por um estágio de transição e de intensidade em que o gesto de fotografar implique um encontro do fotógrafo e do ambiente - pessoas, objetos, nuances, cores. Fotografar no documental imaginário diz respeito a um gesto que carrega consigo a qualidade de indiscernibilidade entre estes elementos e o fotógrafo, demorando-se num mesmo tempo e abarcando a imagem. Em termos de referente, para retomar a discussão de Barthes, esta pode ser uma "fotografia do nada", a imagem sensível de uma atmosfera, do ar ou das cores. É que o referente cede lugar aos meandros do tempo, do acontecimento, não se oferece como prova, como "isto foi”, mas como oportunidade de adentrar labirintos. Elementos como a imersão do fotógrafo, seu envolvimento subjetivo, o carácter ensaístico e narrativo, a implicação dos modelos na construção imagética e uma série de outros aspetos denunciam a importância dos múltiplos afetos, que misturam realizador e personagem com implicações sobre a imagem. Trata-se de uma fotografia que, apesar de instantânea, dedica-se à mudança, ao movimento, com uma predileção pelas trocas afetivas e pelos elementos fluidos, ao invés do que é sólido e firmemente delimitado, objetivo: mesmo que fundada numa experimentação que parte do real.

A performance inscreve-se nesse regime por seu carácter incorporal, permitindo imbricações infinitas entre atual e virtual. Uma característica presente no primeiro cinema - que pode ser descrita

\footnotetext{
${ }^{31}$ Cf. o conceito de expectação (Lissovsky, 2008), sobre a duração e o tempo na fotografia a partir da modernidade fotográfica.
} 
como um certo prazer de objetivar uma realidade e ficcioná-la simultaneamente - se faz possível, mais uma vez, depois da forma estabelecida do cinema se expandir tocando outros campos em expansão, como o da fotografia. Se por um lado o espectador de Sanguinetti tem clara noção da passagem do tempo implicada no conjunto das fotografias, por outro lado ele encontra muito pouco ao buscar ancorar-se num esquema referencial.

Uma orientação documental imaginária é, como notou Bazin (1959) no campo do cinema, a dimensão ética que, nas imagens da reprodutibilidade técnica, garante que não se deva à montagem o que é, por direito, da ordem da ontologia fílmica e fotográfica. Nesse sentido pode-se resgatá-la na fotografia e no cinema por meio da performance: mise-en-place que respeita um carácter documental primeiro das imagens da reprodutibilidade técnica, sem abrir mão de um tipo de montagem no próprio real. Permeada de afetos, é a ontologia fotográfica que compõe o documental imaginário das performances fabulatórias. Na fotografia, a fórmula da performance das personagens reais chega, em seu limite, a produzir imagens de imagens do mundo: imagens do descompasso entre os indivíduos, suas identidades unívocas e um vasto e comum museu imaginário. Neste sentido, o conceito diz respeito à expansão das formas estabelecidas de arte, aponta tendências estéticas mais do que delimita procedimentos e subcategorias.

Se por um lado trata-se de uma tendência da fotografia de realçar a potência da situação fotografada ao abarcar o fotógrafo e seus personagens na duração da imagem (que é, portanto, afetada pelo processo, surge dele), por outro lado, também no cinema a inclinação ao real marcadamente performático esta dimensão afetiva da imagem se fará sentir cada vez mais fortemente. Trata-se, por exemplo, de uma outra invenção da imagem da Ofélia, que, a título de exemplo, aparece no filme Elena (2012) de Petra Costa como personagem performada. No documentário de Costa, que aborda a encenação e os próprios limites do "eu ator" que se caracteriza por querer ser "outro", é justamente esta performance que marca a passagem do individual ao coletivo. Vemos Petra e sua mãe flutuando no rio. $\mathrm{Na}$ sequência uma infinidade de outras mulheres anónimas transfiguram-se de Elena/Ofélia (em referência à irmã suicida da realizadora, mas também à personagem mítica do feminino) e transbordam a questão pessoal da protagonista. As figuras indicam, neste sentido, um modo de sensibilidade contemporânea (notadamente partilhada pelo cinema e pela fotografia) que toca temas complexos (neste caso a identidade e o feminino). Se tais questões não mais podem ser atribuídas aos domínios subjetivo ou objetivo exclusivamente (mas são apontadas num contexto coletivo, como invenção de muitos), resta abordá-las em sua própria permeabilidade, indicando também como articulam vida e arte expandindo-se assim como os diferentes campos artísticos que são, também eles, permeáveis. 


\section{BIBLIOGRAFIA}

Agamben, Giogio. 2000. "Notes on Gesture". In Means Without Ends: Notes on Politics. Minneapolis: University of Minnesota Press.

Barthes, Roland. 1984. A Câmara Clara: nota sobre a fotografia. Rio de Janeiro: Nova Fronteira.

Bergson, Henri. 2005. Evolução criadora. São Paulo: Martins Fontes.

Bazin, André. 1959. "Théâtre et cinéma”. In Qu'est-ce que le cinéma?II Le cinéma et les autres arts. Paris: Ed. Du CERF.

Deleuze, Gilles; Guattari, Félix. 2007. O que é a filosofia? São Paulo: Editora 34.

Deleuze, Gilles. 1996. “O que é o dispositivo”. In O mistério de Ariana. Lisboa: ed. Vega.

-——. 1985. Imagem-movimento: cinema I. São Paulo: Brasiliense.

_-_. 1990. Imagem-tempo: cinema II. São Paulo: Brasiliense.

Didi-Huberman, Georges. 2004. "Knowledge: Movement (the man who spoke to butterflies)". In Michaud, Philippe-Alain. Aby Warburg and the image in motion. New York: Zone Books.

Foucault, Michel. 2004. A arqueologia do saber. Rio de Janeiro: Forense Universitária.

Fernández, Horacio. 2013. Folheto da Exposição Fotolivros LatinoAmericanos. Rio de Janeiro: IMS.

Lins, Consuelo da Luz. 2007. "Ensaio fílmico e humor: o cinema de Agnès Varda”. In Freire Filho, João, Herschman, Micael. (orgs.). Novos rumos da cultura e da mídia: indústrias, produtos, audiências. Rio de Janeiro: Mauad X.

Lissovsky, Maurício. 2008. Máquina de esperar: origem e estética da fotografia moderna. Rio de Janeiro: Mauad X.

Malraux, André. 1965. Le Musée Imaginaire. Paris: Gallimard.

Oiticica, Hélio. 2005. "Cosmococa by Neville D'Almeida", 24/junho/1973. Reproduzido em Cosmococa Program in Progress. Projeto Hélio Oiticica, Fundación Eduardo F. Constantini, Centro de Arte Contemporânea Inhotim, catálogo da exposição realizada em 2005 no MALBA - Buenos Aires: 62- 63.

Païni, Dominique. 2013. "Taking photographs - Sculpting 'au jugé”". Palestra proferida por ocasião da mostra de Mark Cohen na galeria Le Bal, Paris, 4 dezembro.

Parente, André. 2008. "Cinema de exposição: o dispositivo em contra/campo”. Revista Poiésis 12 (nov.): 51-63. 
———. 2011. Cinema em trânsito. Rio de Janeiro: Beco do Azougue.

Pasolini, Pier Paolo. 1976. "The cinema of poetry”. In Nichols, Bill. Movies and Methods: An Anthology. CA: University of California Press.

Pimentel, Mariana Rodrigues. 2010. Fabulação: a memória do futuro. Tese de doutorado (Letras). Pontifícia Universidade Católica, Rio de Janeiro.

Samuels, Chuck. 2004. "Evento fotográfico: projeto cultural e troca de experiências”. Seminário proferido por ocasião do Prémio Foto Arte 2004, Brasília, CCBB, 20 junho.

Sanguinetti, Alessandra. 2003. "The Adventures of Guille and Belinda and the Enigmatic Meaning of Their Dreams". In Light Work: Contact Sheet 120.

-_- 2010. The adventures of Guille and Belinda and The Enigmatic Meaning of their Dreams. Portland: Nazraeli Press.

Showalter, Elaine. 1985. "Representing Ophelia: Women, Madness, and the Responsibilities of Feminist Criticism". In Shakespeare and the Question of Theory, ed. Patricia Parker and Geoffrey Hartman. Methuen: 77-94.

Youngblood, Gene. 1970. Expanded Cinema. New York: E. P. Dutton \& Co., Inc. 